Biosensors and Bioelectronics

January 2006; 21(7) : 1355-1358

http://dx.doi.org/10.1016/j.bios.2005.05.013

(c) 2005 Elsevier B.V. All rights reserved
Archimer, archive institutionnelle de l'Ifremer http://www.ifremer.fr/docelec/

\title{
Oligonucleotide quartz crystal microbalance sensor for the microalgae Alexandrium minutum (Dinophyceae)
}

\author{
M. Lazerges ${ }^{a}$, H. Perrot ${ }^{a^{*}}$, E. Antoine $^{b}$, A. Defontaine ${ }^{b}$ and C. Compere ${ }^{c}$
}

\author{
aLISE, CNRS-Université Pierre et Marie Curie, 4 place Jussieu, 75252 Paris cedex 05, France \\ bIfremer, Centre de Nantes, rue de l'lle d'Yeu, BP 21105, 44311 Nantes Cedex 3, France \\ ${ }^{c}$ Ifremer, Centre de Brest, B.P. 70, 29280 Plouzané, France \\ *: Corresponding author : Tel.: +33 1442772 16; fax: +33 1442740 74. perrot@ccr.jussieu.fr
}

\begin{abstract}
We report the immobilization on a gold surface of a 20-base DNA probe labeled with disulfide group and on the selective hybridization with the complementary 20-base DNA strand. The oligonucleotide probe is the complementary strand of a partial sequence of the gene encoding for a large ribosomal RNA sub-unit which is a coding sequence of Alexandrium minutum DNA, a microalgae that produces neurotoxins responsible for paralytic shellfish poisoning on European and Asian coasts. The kinetics of DNA probe immobilization and hybridization were monitored in situ by using a $27 \mathrm{MHz}$ quartz crystal microbalance under controlled hydrodynamic conditions. The frequency of the setup is stable to within a few hertz, corresponding to the nanogram scale, for $3 \mathrm{~h}$ and makes it possible to follow frequency change from immobilization of the probe to hybridization of the complementary DNA target. This setup constitutes a biosensor, which is sensitive and selective, and the hybridization ratio between hybridized complementary DNA and immobilized DNA probes is $47 \%$.
\end{abstract}

Keywords: Microbalance; Alexandrium minutum; DNA 


\title{
Oligonucleotide quartz crystal microbalance sensor for the microalgae Alexandrium minutum (Dinophyceae)
}

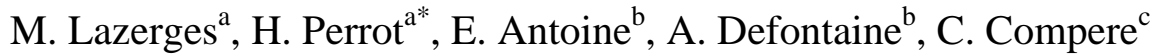 \\ ${ }^{a}$ LISE, CNRS-Université Pierre et Marie Curie, 4 place Jussieu, 75252 Paris cedex 05, France. \\ ${ }^{b}$ Ifremer, Centre de Nantes, rue de l'Ile d'Yeu, BP 21105, 44311 Nantes Cedex 3, France \\ ${ }^{c}$ Ifremer, Centre de Brest, B.P. 70, 29280 Plouzané, France
}

\begin{abstract}
We report the immobilization on a gold surface of a 20-base DNA probe labeled with disulfide groups and on the selective hybridization with the complementary 20-base DNA strand. The oligonucleotide probe is the complementary strand of a partial sequence of the gene encoding for a large ribosomal RNA sub-unit which is a coding sequence of Alexandrium minutum DNA, a microalgae that produces neurotoxins responsible for paralytic shellfish poisoning on European and Asian coasts. The kinetics of DNA probe immobilization and hybridization were monitored in situ by using a $27 \mathrm{MHz}$ quartz crystal microbalance under controlled hydrodynamic conditions. The frequency of the set up is stable to within a few hertz, corresponding to the nanogram scale, for 3 hours and makes it possible to follow frequency change from immobilization of the probe to hybridization of the complementary target DNA. This setup constitutes a biosensor which is sensitive and selective, and the hybridization ratio between hybridized complementary DNA and immobilized DNA probes is $47 \%$.
\end{abstract}

Keywords: microbalance, Alexandrium minutum, DNA

\section{Introduction}

The microalgae Alexandrium minutum (-Halim, 1960; Balech, 1989; Bolch et al, 1991) produces neurotoxins which can be accumulated in shellfish and are responsible for damage to human health. This species recurrently forms toxic blooms in the northern part of the Brittany coast in France (Nezan et al, 1989; Belin, 1993; -Erard, 1990), southern Taiwan coast (Hwang et al, 1999), northern Adriatic waters (-Honsell, 1993) and New Zealand coasts ( Chang et al, 1997). At present, algae identification relies on tedious microscope observations mostly performed by skilled taxonomists in laboratories. More recently real-time PCRs were performed to detect Alexandrium minutum from the Catalan coast (Galluzzi et al, 2004). Gravimetric sensors are useful for the design of sensitive and selective in situ biosensors (Bizet et al, 1997; Minunni et al 2003; Su et al, 1997) and appear as promising tools for the detection of toxic blooms in the framework of coastal water monitoring. We report in this work the immobilization on a gold surface of a 20-base DNA probe labeled with disulfide on a gold surface and the hybridization with the complementary 20-base DNA strand. The sequence of the oligonucleotide probe is a partial sequence of the gene encoding for the large ribosomal RNA sub-unit of Alexandrium minutum (Guillou, 2002).

\footnotetext{
* corresponding author
} 


\section{Experimental section}

\subsection{Chemical and biochemical reagents}

$\mathrm{H}_{2} \mathrm{SO}_{4}$ (95\%), $\mathrm{H}_{2} \mathrm{O}_{2}$ (30\% in water), $\mathrm{NaOH}, \mathrm{HCl}, \mathrm{MgCl}_{2}, \mathrm{NaCl}, 1 \mathrm{M}$ 2-[4-(2hydroxyethyl)-1-piperazine]ethanesulfonic acid buffer (HEPES), $1 \mathrm{M}$ tris(hydroxymethyl)aminomethane buffer, sodium dodecyl sulfate (SDS), sodium citrate, casein, were from Sigma Aldrich. All chemicals reagents were of biochemical quality. DIG Oligonucleotide tailing kit was from Roche Diagnostic. Anti-DIG-alkaline phosphatase conjugate $(150 \mathrm{mU} / \mathrm{mL})$, nitroblue tetrazolium salt (NBT) and 5-bromo-4-chloro-3-indolyl phosphate toluidinium salt (BCIP) were from Biorad. Water used in all experiments was deionized and double distilled. 5'- $\mathrm{H}_{3} \mathrm{C}\left(\mathrm{CH}_{2}\right)_{5}-\mathrm{S}-\mathrm{S}-\left(\mathrm{CH}_{2}\right)_{6}$-AGCACTGATGTGTAAGGGCT3' (DNA-disulfide probe), 5'-AGCCCTTACACATCAGTGCT-3' (complementary DNA), phosphatase-5'-AGCCCTTACACATCAGTGCT-3' (complementary DNA-phosphatase) and 5'-CCTTGGTCCGTGTTTCAAGA-3' (non-complementary DNA) were from Eurogentec. The disulfide labeled oligonucleotide was synthesized by a crosslinked reaction (Atsushi et al, 1990). Purity of DNA chains was checked by chromatography, MALDI-TOF analysis and UV optical density measurements. Nylon transfer membranes, Nytran SuperCharge from Schleicher \& Schuell, were used for control hybridization experiments.

\subsection{Buffers and solutions}

The hybridization buffer for control experiments on nylon was $0.6 \mathrm{M} \mathrm{NaCl}, 60 \mathrm{mM}$ sodium citrate, $1 \%$ blocking reagent (Roche), $0.1 \%$ sarkosyl (N-lauroylsarcosine), $0.02 \%$ SDS adjusted to $\mathrm{pH}$ 7.0. Post-hybridization washing solutions were prepared from 20X SSC (3M $\mathrm{NaCl}, 300 \mathrm{mM}$ sodium citrate, $\mathrm{pH}$ 7.2) and 10\% SDS. Tris Buffer for the color development solution was $0.1 \mathrm{M}$ Tris, $0.5 \mathrm{mM} \mathrm{MgCl}_{2}$, $\mathrm{pH}$ 9.5. The hybridization buffer for QCM experiments was $0.05 \mathrm{M}$ HEPES 4 and $0.5 \mathrm{M} \mathrm{NaCl}$ adjusted to $\mathrm{pH} 7.43$ with drops of $1 \mathrm{M}$ $\mathrm{NaOH}$, referred to as 'HEPES'.

\subsection{Hybridization protocol on Nylon membrane}

Nylon membrane: $50 \mu \mathrm{L}$ of a $100 \mu \mathrm{M}$ solution in sterile distilled water of the DNA-disulfide probe, of a non-disulfide-labeled same-sequence probe as positive control, and of a noncomplementary probe as negative control were spotted on a positively charged nylon membrane (Sambrook et al., 1989) using a filtration manifold (Schleicher \& Schuell). The membrane was let to dry and cross linked by U.V. exposition for 3 minutes. Prior to hybridization $2 \mu \mathrm{L}$ of $50 \mu \mathrm{M}$ complementary strand were labeled with Digoxygenin-dUTP according to the DIG Oligonucleotide tailing kit and diluted in $10 \mathrm{~mL}$ hybridization buffer (final concentration $10 \mathrm{nM}$ ). The hybridization steps were 30 minutes at $37^{\circ} \mathrm{C}$ for prehybridization, 2 hours at $37^{\circ} \mathrm{C}$ for hybridization and followed by stringency washing steps (2X5 minutes at room temperature in $2 \mathrm{X}$ SSC / 0.1\% SDS, $2 \mathrm{X} 15$ minutes at $37{ }^{\circ} \mathrm{C}$ in $0.1 \mathrm{X}$ SSC / 0.1\% SDS). DIG-labeled hybrids were detected with an anti-DIG-alkaline phosphatase conjugate $(150 \mathrm{mU} / \mathrm{mL})$ and the substrates NBT and BCIP, which give a light-blue precipitate. Just prior to use, $1 \mathrm{ml}$ of $30 \mathrm{mg} / \mathrm{mL}$ NBT and $1 \mathrm{~mL}$ of $15 \mathrm{mg} / \mathrm{mL}$ BCIP were mixed in $100 \mathrm{~mL}$ of Tris Buffer. The nylon membrane was immersed in the color development solution. BCIP and NBT are two colorless substrates which form a redox system. BCIP is oxidized by alkaline phosphatase to indigo by release of a phosphate group. In parallel NBT is reduced to diformazan. The reaction products form a water insoluble dark blue precipitate on the membrane. 
AT-cut planar quartz crystals $14 \mathrm{~mm}$ diameter with a $9 \mathrm{MHz}$ nominal resonance frequency (Matel Fondhal France) were used. Two identical gold electrodes, $2000 \AA$ thick and $5 \mathrm{~mm}$ in diameter, were deposited by evaporation techniques on both sides of crystals with a chromium underlayer. The gold side used in the experiments was cleaned with a $10 \mu \mathrm{L}$ drop of $50 \% \mathrm{H}_{2} \mathrm{SO}_{4}, 50 \% \mathrm{H}_{2} \mathrm{O}_{2}$ for 30 minutes and rinsed with deionized double distilled water. The resonators were connected with a silver conducting paste, through wires, to a BNC adaptator. A home-made oscillator was designed to drive the crystal at $27 \mathrm{MHz}$ which corresponds to the third overtone of the quartz resonator. To improve the stability, all the electronic oscillator components where temperature-controlled by a Watlow heater current monitor with a stability better than $0.1 \mathrm{~K}$. An experimental cell was developed: the crystal was mounted between two O-ring seals inserted in a plexiglass cell. Only one face of the quartz was in contact with the solutions. The cell volume was $50 \mu \mathrm{L}$. The apparatus included a P1 micropump (Pharmacia) to assure a $20 \mu \mathrm{L} / \mathrm{min}$ constant flow of the solutions. The experiments were performed at $22^{\circ} \mathrm{C}$, the room temperature. The experimental QCM setup consisted of the $27 \mathrm{MHz}$ QCM and a frequency counter PM 6685. The experimental setup was computer controlled by home-made software in $\mathrm{C}$ language. 


\section{Results}

\subsection{Hybridization on nylon}

Hybridization experiments were first performed on nylon membrane to check the hybridization properties of the DNA-disulfide probe. Positive hybridizations were obtained with the DNA-disulfide probe and the non-disulfide-labeled same-sequence probe. With the non-complementary probe used as control hybridization was negative. Results of the colorimetric detection test are presented in figure 1.

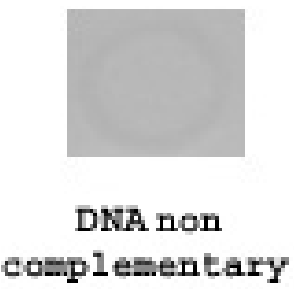

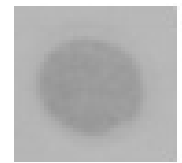

DNA complementary

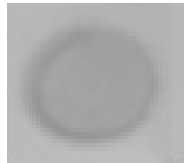

DNA-disulfide complementary

Fig. 1. Hybridization experiments on nylon

The hybridization properties of the DNA-disulfide probe were not changed by the 5'end disulfide labeling.

\subsection{Hybridization on quartz crystal microbalance}

Immobilization of a DNA-disulfide probe, a selective hybridization test with a noncomplementary DNA and hybridization with a complementary DNA chain were performed on the gold electrode of a quartz resonator by successive circulation of $\mathrm{NaCl}$, HEPES and DNA solutions. The experimental conditions were already optimized: $\mathrm{pH} 7.4$ and $0.5 \mathrm{M} \mathrm{NaCl}$, the conditions of Zhou et al. (Zhou et al, 2001) who designed a 18-base DNA-disulfide probe gravimetric sensor. The frequency shift during circulation at a $50 \mu \mathrm{L} / \mathrm{min}$ flow rate of successive solutions in the quartz cell is presented in figure 2 . 


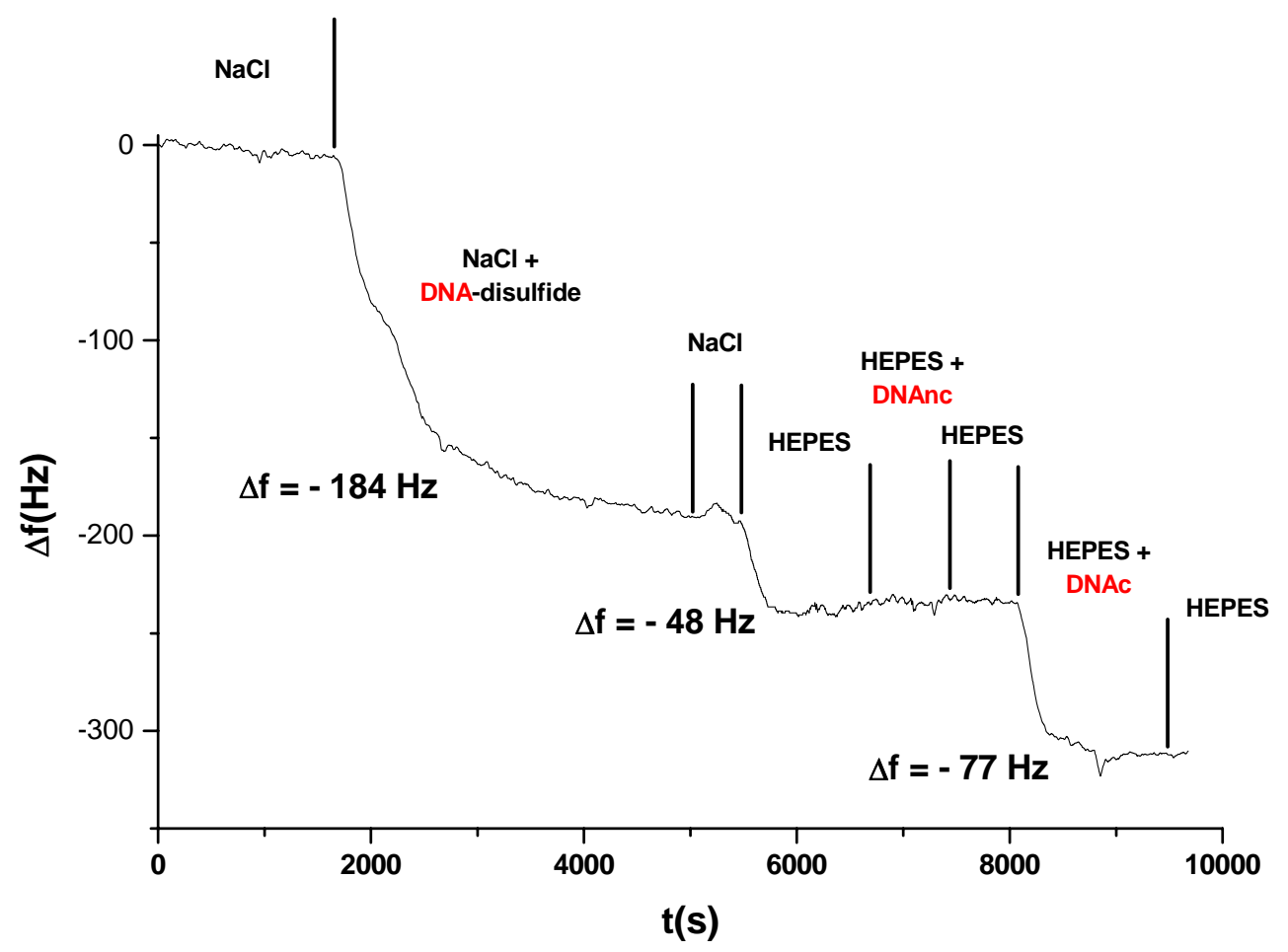

Fig. 2. Microbalance frequency change successive circulation of $20 \mu \mathrm{g} / \mathrm{mL}$ DNA-disulfide NaCl solution, 20 $\mu \mathrm{g} / \mathrm{mL}$ non complementary DNA HEPES solution and $20 \mu \mathrm{g} / \mathrm{mL}$ complementary DNA HEPES solution

The first step, the immobilization of the DNA-disulfide probe, was performed by circulation of a $20 \mu \mathrm{g} / \mathrm{mL}$ DNA-disulfide solution. The frequency change observed is -184 $\mathrm{Hz}$, as shown in figure 2. The coverage of the surface is estimated to be $66 \%$, taking into account the experimental microbalance sensitivity $(350 \mathrm{pg} / \mathrm{Hz})$, the active surface of the QCM $\left(0.2 \mathrm{~cm}^{2}\right)$, the molecular weight of the DNA-disulfide $(6448 \mathrm{~g} / \mathrm{mol})$ and the average area of one molecule of adsorbed DNA-disulfide $\left(2.2 \mathrm{~nm}^{2}\right.$ ) (Zhou et al, 2004). The frequency change of $-48 \mathrm{~Hz}$ is attributed to the change of viscosity between $0.5 \mathrm{M} \mathrm{NaCl}$ and HEPES buffer. The second step that allows the selectivity to be checked was performed by circulation of 20 $\mu \mathrm{g} / \mathrm{mL}$ non complementary DNA (DNAnc) solution in HEPES. There was no frequency change during the flowing of this solution (figure 2). This means that there is no hybridization or non-specific adsorption of the non-complementary DNA chain. The third and last step, hybridization, was performed by circulation of a $20 \mu \mathrm{g} / \mathrm{mL}$ complementary DNA (DNAc) solution in HEPES. The frequency change observed was $-77 \mathrm{~Hz}$ (figure 2). The hybridization ratio of hybridizing complementary DNA versus immobilized DNA-disulfide probes is $45 \%$, taking into account the molecular weight of the DNA-disulfide probe and of the complementary DNA (6055 g/mol). This experiment was reproductible, it was done 4 times; the mean value of the coverage is $67 \%$ (SD 3.1\%) and the mean value of the hybridization ratio is $47 \%$ (SD $2.6 \%$ ).

\section{Conclusions}

We have designed a selective and sensitive 20-base oligonucleotide gravimetric biosensor with a $47 \%$ hybridization ratio for a coding sequence of Alexandrium minutum DNA. The biosensor is stable at the nanogram scale for 3 hours, which allows us to 
follow frequency change from immobilization of the probe to selective hybridization of the complementary target DNA. This is the first gravimetric biosensor for Alexandrium minutum and the first step towards the design of a biosensor for real-time coastal water monitoring of this harmful microalgae. We will present a complete thermodynamic and kinetic hybridization study in a subsequent full paper.

\section{Aknowledgements}

We wish to thank the French Ministry of Research for its financial support (ACI CAPALEX) and John Lomas for fruitful discussions. 


\section{References}

Atsushi, A., Akira, M., 1990. Production of Oligonucleotide Probe. Patent 63-19-1087.

Balech, E., 1989. Rediscription of Alexandrium minutum (Dinophyceae) type species of the genus Alexandrium. Phycologia 28, 206-211.

Belin, C., 1993. Toxic Phytoplankton Blooms in the Sea, Elsevier, Amsterdam, 469-474.

Bizet, K., Gabrielli C., Perrot H., Therasse J., 1998. Validation of antibody-based recognition by piezzoelectric transducers through electroacoustic admittance analysis. Biosensors and Bioelectronics 13, 259-269.

Bolch, C.J., Blackburn S.I., Cannon, J.A., Hallegraeff, G.M., 1991. The resting cyst of the red-tide dinoflagellate Alexandrium minutum (Dinophyceae). Phycologia 30, 215-219.

Chang, F. H., Anderson, D. M., Kulis, D. M., Till D. G., 1997. Toxin production of Alexandrium minutum (Dinophyceae) from the Bay of Plenty, New Zealand. Toxicon 35, 393-409.

Erard, E., 1990. Recent Approaches on Red Tides, Park J.S. and H. G. Kim Eds, 85-98.

Galluzzi, L., Penna, A., Bertozzini, E., Vila M., Garcés E., Magnani M., 2004. Development of a real-time PCR assay for rapid detection and quantification of Alexandrium minutum (a Dinoflagellate). Appl. and Env. Micr. 70, 1199-1206.

Guillou L., Nezan E, Cueff V, Erard-Le Denn E., Cambon-Bonavita M.A., Gentien P., Barbier G., 2002. Genetic diversity and molecular detection of three toxic dinoflagellate genera (Alexandrium, Dinophysis, and Karenia) from French coasts. Protist, 153 pp. 223-238.

Halim, Y., 1960. Alexandrium minutum, n. gen. n. sp. Dinoflagellé provocant des “eaux rouges”. Vie et Milieu $11,102-105$.

Honsell, G., 1993. Toxic Phytoplankton Blooms in the Sea, Elsevier, Amsterdam, 127-132.

Hwang, D.-F., Tsai Y.-H., Liao H.-J., Matsuoka, K., Noguchi, T., Jeng, S.-S., 1999. Toxins of the dinoflagellate Alexandrium minutum Halim from the coastal waters and aquaculture ponds in Southern Taiwan. Fish. Sci. 65, 171-172.

Minunni, M., Tombelli, S., Scielzi, R., Mannelli, I., Mascini, M., Gaudiano, C., 2003. Detection of $\beta$-thalassemia by DNA piezoelectric biosensor coupled with polymerase chain reaction. Analytica Chim. Acta 481, 5564.

Nezan, E., Belin, C., Lassus, P., Piclet G., Berthome, J.P., 1989. Alexandrium minutum: first PSP species occurrence in France, Fourth International Conference on Toxic Marine Phytoplankton, Lund, Sweden, 111.

Sambrook, J., Fritsch, E.F., Maniatis, T., 1989. Molecular Cloning. Cold Spring Harbor Laboratory Press, U.S, 7-53, 7-54.

Su, H., Chong, S., Thompson, M., 1997. Kinetics of hybridization of interfacial RNA homopolymer studied by thickness-shear mode acoustic wave sensor. Biosensors and Bioelectronics 12, 161-173.

Zhou, C. X., Huang, L.Q., Li, S.F.Y., 2001. Microgravimetric DNA sensor based on quartz crystal microbalance: comparison of oligonucleotide immobilization methods and the application in genetic diagnosis. Biosensors and Bioelectronics 16, 85-95. 